\title{
The EU Top Court Rules that Married Same-Sex Couples Can Move Freely Between EU Member States as "Spouses": Case C-673/16, Relu Adrian Coman, Robert Clabourn Hamilton, Asociația Accept v Inspectoratul General pentru Imigrări, Ministerul Afacerilor Interne
}

\author{
Alina Tryfonidou ${ }^{1}[$ \\ Published online: 23 April 2019 \\ ๑) The Author(s) 2019, corrected publication 2019
}

\begin{abstract}
In the Coman case, the European Court of Justice was asked whether the term "spouse"-for the purposes of EU law-includes the same-sex spouse of an EU citizen who has moved between EU Member States. The ECJ answered this question affirmatively, holding that a refusal to recognise a same-sex marriage and the resultant refusal to grant family reunification rights to a Union citizen who moves to another Member State, would constitute an unjustified restriction on the right to free movement that Union citizens enjoy under EU law. This case comment analyses the judgment, arguing that the Court's pronouncement is a very welcome first step towards marriage equality at a cross-border level in the EU. At the same time, following the delivery of this ruling, a lot of questions have arisen and gaps in the protection of same-sex couples persist, and these are also analysed in this piece.
\end{abstract}

Keywords EU free movement law · Family reunification rights · LGB rights · Marriage equality $\cdot$ Romania $\cdot$ Same-sex marriage

\section{Introduction}

In the recent case of Coman, ${ }^{1}$ the European Court of Justice ("ECJ" or "The Court") was asked to rule on the meaning of "spouse", for the purposes of EU free movement law. In particular, the national court which made the reference to the ECJ,

\footnotetext{
${ }^{1}$ Coman, Hamilton and Asociatia Accept v Inspectoratul General pentru Imigrări and Ministerul Afacerilor Interne (C-673/16) EU:C:2018:385.
}

Alina Tryfonidou

a.tryfonidou@ reading.ac.uk

1 Foxhill House, School of Law, University of Reading, Whiteknights Road, Earley,

Reading RG6 7BA, UK 
wished to know whether the term includes the same-sex spouse of a European Union ("EU" or "Union") citizen who has exercised EU free movement rights and wishes to be joined by his/her same-sex spouse in the Member State to which (s)he moves. The ECJ answered this question affirmatively, holding that if the Member State to which an EU citizen moves refuses to recognise his/her same-sex marriage and, thus, refuses to grant to him/her family reunification rights with his/her same-sex spouse, this will constitute an unjustified restriction on the right to free movement that Union citizens enjoy under EU law.

This case comment aims to analyse the Coman judgment, arguing that it is a very welcome first step towards marriage equality at a cross-border level in the EU. At the same time, following the delivery of this ruling, a number of issues remain unaddressed whilst gaps in the protection of same-sex couples persist and, thus, an analysis of these will also be provided.

\section{Legal and Factual Background}

The EU has always had as one of its core objectives to ensure that EU Member State nationals-who, since 1993, are also EU citizens ${ }^{2}$ — can move freely between Member States. The Treaties have, therefore, always included provisions which prohibit obstacles to the free movement of persons, these, currently, being Articles 21, 45, 49, and 56 of the Treaty on the Functioning of the European Union ("TFEU"). ${ }^{3}$ One of the ways that an obstacle to free movement can emerge is if the Union citizen who moves to another Member State is not allowed to be joined by his/her close family members. Accordingly, the Court in its case-law has made it clear that the free movement provisions of the Treaty require Member States to accept within their territory the close family members of Union citizens who exercise free movement rights, ${ }^{4}$ whilst this has been reflected also in secondary EU legislation which has been promulgated since the 1960s. The source of family reunification rights for Union citizens who move to a Member State other than that of their nationality is, currently, Directive 2004/38. ${ }^{5}$ ECJ case-law has made it clear that although secondary legislation (including the 2004 Directive) does not directly apply to Union citizens who move back to their Member State of nationality after having exercised their free movement rights, such situations are, nonetheless, covered directly by the

\footnotetext{
${ }^{2}$ Currently provided by Article 20 Treaty on the Functioning of the European Union ("TFEU"). For more on the status of Union citizenship see Barnard (2016, Chap. 10).

${ }^{3}$ For a clear explanation of the legal framework created by the free movement of persons provisions see Barnard (2016, Chaps. 7-12).

${ }^{4}$ See, for instance, Carpenter $v$ Secretary of State for the Home Department (C-60/00), EU:C:2002:434. For an analysis of the EU's approach towards the grant of family reunification rights to Union citizens who exercise their free movement rights see Berneri 2017.

5 Directive 2004/38 on the right of citizens of the Union and their family members to move and reside freely within the territory of the Member States [2004] OJ L 158/77.
} 
free movement provisions. ${ }^{6}$ The Court has also ruled that the provisions of Directive 2004/38 which grant family reunification rights to Union citizens who move to another Member State must apply, by analogy, also to Union citizens who return to their Member State of nationality after exercising their free movement rights. ${ }^{7}$

Directive 2004/38 provides, inter alia, that Union citizens can be joined or accompanied by their family members in the Member State to which they move, i.e. that Member State must automatically admit the family members to-and grant them a right of residence in-its territory. The nationality of the family members is not important (i.e. they do not need to be Union citizens), and, in practice, it is family members who are third-country nationals that mostly need to rely on EU family reunification rights, as family members who are Union citizens themselves enjoy the right to move and reside freely in any Member State. "Family members" are defined in Article 2(2) of the Directive and include "the spouse" of the Union citizen.

In the Coman case it was, exactly, the interpretation of this provision that was at issue and, in particular, the question was whether the term "spouse" includes the same-sex spouse of a Union citizen who exercises free movement rights.

The facts of the case were as follows: Mr. Coman (who holds Romanian and US nationality) and Mr. Hamilton (who holds US nationality) met in the US in 2002 and lived there together from 2005 to 2009, when Mr. Coman took up residence in Brussels. The couple married in Belgium in 2010. They subsequently contacted the Romanian General Inspectorate for Immigration, to enquire whether Mr. Hamiltonin his capacity as Mr. Coman's spouse - could obtain the right to reside lawfully in Romania on the basis of EU law, together with Mr. Coman who wished to return to Romania, his Member State of nationality. The Romanian authorities replied in the negative, noting that Mr. Hamilton cannot be recognised as Mr. Coman's spouse, as under Romanian law, same-sex marriages are prohibited and same-sex marriages entered into abroad are not recognised. ${ }^{8}$

The couple, then, brought an action against the decision of the Inspectorate, seeking a declaration of discrimination on the ground of sexual orientation as regards the exercise of EU free movement rights. They also argued that the Romanian legislation which does not recognise same-sex marriages entered into abroad is unconstitutional, in that it infringes the provisions of the Romanian Constitution that protect the right to personal life, family life and private life, and the provisions relating to equality. The first instance court hearing the case referred the matter to the Romanian Constitutional Court which, in its turn, decided to stay the proceedings and make a reference for a preliminary ruling to the ECJ, ${ }^{9}$ asking, essentially, whether a

\footnotetext{
${ }^{6}$ The Queen v. Immigration Appeal Tribunal and Surinder Singh (C-370/90), EU:C:1992:296; Minister voor Vreemdelingenzaken en Integratie v R. N. G. Eind (C-291/05), EU:C:2007:771.

${ }^{7} O$ and $B$ v Minister voor Immigratie, Integratie en Asiel (Case C-456/12), EU:C:2014:135.

${ }^{8}$ Law no. 287/2009 Codul civil al României, art. 277.

${ }^{9}$ The preliminary ruling procedure-laid down in Article 267 TFEU - enables national courts which are unsure about the interpretation of an EU law provision or the validity of a piece of EU secondary legislation to stay the proceedings before them and make a reference for a preliminary ruling to the ECJ asking for clarification of the matter. Once the ECJ clarifies the matter through a binding ruling, the referring national court can resume the proceedings before it and taking into account the clarification provided by the ECJ, it will decide the case.
} 
Union citizen who has exercised free movement rights can enjoy EU family reunification rights with his same-sex spouse in the Member State to which he moves.

\section{The Court's Judgment}

The Court answered the above question in the affirmative holding that the term "spouse" in Article 2(2)(a) of Directive 2004/38 includes the same-sex spouse of a Union citizen.

The Court began the main part of its analysis by pointing out that "the term 'spouse' used in that provision refers to a person joined to another person by the bonds of marriage", ${ }^{10}$ whilst it also noted that it is "gender-neutral and may therefore cover the same-sex spouse of the Union citizen concerned". ${ }^{11}$ In addition, the Court stressed that the Directive does not make reference to national legislation for the purpose of determining the meaning of the term "spouse". 12

It was, then, highlighted that "a person's status, which is relevant to the rules on marriage, is a matter that falls within the competence of the Member States" and "Member States are thus free to decide whether or not to allow marriage for persons of the same sex". ${ }^{13}$ Yet, as is well-established, "in exercising that competence, Member States must comply with EU law, in particular the Treaty provisions on the freedom conferred on all Union citizens to move and reside in the territory of the Member States". ${ }^{14}$ The Court then, proceeded, to note that:

the refusal by the authorities of a Member State to recognise, for the sole purpose of granting a derived right of residence to a third-country national, the marriage of that national to a Union citizen of the same sex, concluded, during the period of their genuine residence in another Member State, in accordance with the law of that State, may interfere with the exercise of the right conferred on that citizen by Article 21(1) TFEU to move and reside freely in the territory of the Member States. Indeed, the effect of such a refusal is that such a Union citizen may be denied the possibility of returning to the Member State of which he is a national together with his spouse. ${ }^{15}$

The analysis then proceeded to consider whether such a restriction to free movement can, nonetheless, be justified a) on the ground that the EU is required, under Article 4(2) TEU, to respect the national identity of the Member States and b) on the ground of public policy. ${ }^{16}$ The Court concluded that it cannot, noting that:

${ }^{10}$ Coman Judgment supra n 1, [34].

${ }^{11}$ Coman Judgment supra n 1, [35].

${ }^{12}$ Coman Judgment supra n 1, [36].

13 Coman Judgment supra n 1, [37].

${ }^{14}$ Coman Judgment supra n 1, [38].

15 Coman Judgment supra n 1, [40].

${ }^{16}$ Coman Judgment supra n 1, [43, 44]. 
the obligation for a Member State to recognise a marriage between persons of the same sex concluded in another Member State in accordance with the law of that state, for the sole purpose of granting a derived right of residence to a third-country national, does not undermine the institution of marriage in the first Member State, which is defined by national law and ... falls within the competence of the Member States. Such recognition does not require that Member State to provide, in its national law, for the institution of marriage between persons of the same sex. It is confined to the obligation to recognise such marriages, concluded in another Member State in accordance with the law of that state, for the sole purpose of enabling such persons to exercise the rights they enjoy under EU law. ${ }^{17}$

The Court then, also, stressed that in any event, "a national measure that is liable to obstruct the exercise of freedom of movement for persons may be justified only where such a measure is consistent with the fundamental rights guaranteed by the Charter". ${ }^{18}$ It was, then, explained that as regards the term "spouse", the right to respect for private and family life is protected under Article 7 of the EU Charter of Fundamental Rights ("EUCFR" or "Charter"), ${ }^{19}$ and, in accordance with Article 52(3) of the same instrument, the rights guaranteed by the Charter have the same meaning and scope as those guaranteed by the European Convention on Human Rights. ${ }^{20}$ The Court's analysis in relation to this matter was, however, confined to pointing out that

It is apparent from the case-law of the European Court of Human Rights that the relationship of a homosexual couple may fall within the notion of "private life" and that of "family life" in the same way as the relationship of a heterosexual couple in the same situation. ${ }^{21}$

Hence, the Court based its judgment solely on a free movement based-argument, without-as suggested by a number of commentators (Tryfonidou 2015; Bell and Bačić Selanec 2016; Rijpma and Koffeman 2014) —using human rights as a separate-independent-legal base for finding a breach of EU law.

\section{Comment}

\section{Marriage Equality in the EU}

Europe has, until recently, boasted the most progressive laws governing the recognition of same-sex relationships, with Denmark being the first country in the world to introduce same-sex registered partnerships (in 1989) and the Netherlands being the

\footnotetext{
17 Coman Judgment supra n 1, [45].

18 Coman Judgment supra n 1, [47].

19 Charter of Fundamental Rights of the European Union [2012] OJ C 326/02.

20 Coman Judgment supra n 1, [49].

21 Coman Judgment supra n 1, [50].
} 
first country to introduce same-sex marriage (in 2001). In fact, currently all western EU Member States make provision for legal recognition of same-sex relationships, though there remains considerable diversity between the types of legal status being afforded. At the same time, there are still six EU Member States ${ }^{22}$-all situated in eastern Europe-which do not offer any legal recognition to same-sex relationships whilst there are seven EU Member States-again, all situated in eastern Europethat maintain a constitutional ban on same-sex marriage. ${ }^{23}$

The question, of course, is whether the existence of such a legal patchwork is permissible under EU law. The answer to the above question is that it is fully within the rights of the Member States to decide whether they will offer legal recognition to same-sex relationships within their territory, and if they do so, what exact form this will take. This is because family law and, thus, questions, regarding the legal recognition of relationships and the corresponding civil status, fall within the realm of Member State competence (Toner 2004; Lenaerts 2011). ${ }^{24}$ Yet, as with other areas where the Member States maintain full competence and the EU cannot legislate, it is clear that with regards to family law and, in particular, the legal recognition of samesex relationships, Member States must comply with EU law when exercising their competence. $^{25}$

The scenario in Coman is precisely an example of a situation where the exercise of Member State competence in the family law field could give rise to a breach of EU law. In this case, Romania prohibited same-sex marriage in its territory. This is not problematic from the point of view of EU law, since Member States are free to determine whether they will open marriage to same-sex couples in their territory. However, Romania's decision not only to prohibit same-sex marriage in its territory, but, also, to refuse to recognise same-sex marriages contracted elsewhere, did amount to a breach of EU law, in situations where an EU citizen coming from another Member State sought to claim family reunification rights in its territory. This was for the simple reason that the failure to recognise that citizen's marriage and the resultant refusal to allow his spouse to live with him in Romania, would clearly impede his right to free movement.

When the EU institutions were discussing, in the early 2000s, the proposal of what later became Directive 2004/38, the issue of same-sex marriage came up, with different institutions having different views as to whether the term "spouse" should include same-sex spouses (Bell 2004). Given the controversy surrounding the matter and the fact that, at the time, only two EU Member States had opened marriage to same-sex couples, a compromise position was adopted, whereby the gender- and sexual orientation-neutral term "spouse" was used alone, without offering any clarification as to its meaning. ${ }^{26}$

\footnotetext{
22 Bulgaria, Latvia, Lithuania, Poland, Romania, Slovakia.

23 Bulgaria, Croatia, Hungary, Latvia, Lithuania, Poland, and Slovakia.

24 Coman Judgment supra n 1, [37]; Parris (C-443/15) EU:C:2016:897, [59]; Maruko (C-267/06) EU:C:2008:179, [59].

25 Coman Judgment supra n 1, [38]; Parris, Judgment supra n 24, [58].

${ }^{26}$ See the analysis of Advocate General Wathelet in his Opinion in Coman, EU:C:2018:2, [51, 52].
} 
It was thus left to the ECJ to clarify the meaning of this term, and, as we saw, the Court did so with its judgment in Coman. In choosing to rule that the term includes same-sex spouses, the ECJ may have been influenced by the two recent rulings of the US Supreme Court with which the latter gradually provided full and complete recognition for married same-sex couples in the US, for all legal purposes (Titshaw 2016). ${ }^{27}$ With Coman however, the ECJ seems to have only partly followed the steps of the US Supreme Court, as it has not ruled that EU Member States are requiredby EU law-to open marriage to same-sex couples. The scope of the Coman ruling is much narrower, in that it simply made it clear that EU Member States must recognise same-sex marriages contracted in other EU Member States, in situations where a Union citizen moves between Member States and, in particular, when (s)he claims family reunification rights under EU law. The judgment seems to, also, be implying that same-sex marriages must now be recognised for all EU law purposes (i.e. not just when determining when EU family reunification rights must be granted): if, as the judgment states, albeit quite vaguely, ${ }^{28}$ failing to recognise same-sex marriages in the same way as opposite-sex marriages breaches fundamental human rights protected under the EUCFR, EU law provisions-which must comply with the Charter-should be read in a way which provides for marriage equality and the EU institutions - which are bound by the Charter-must recognise same-sex marriages as equal to opposite-sex marriages for all purposes. Yet, respecting the constraints on the EU's competence, the judgment clearly does not interfere with the choices of Member States as regards marriage equality in situations that fall outside the scope of EU law. Accordingly, with its ruling in Coman, the ECJ has gone as far as it can go, in terms of marriage equality, since the EU does not have the competence to require Member States to open marriage to same-sex couples in their territory (Bell and Bačić Selanec 2016).

\section{The Importance of Coman}

The ruling in Coman will ensure a high level of legal certainty and transparency, as married same-sex couples comprised of one EU citizen, will now know that they will be recognised in every Member State to which they move, at least for the purposes of family reunification.

At the same time, it is likely that the ruling will lead to some backlash, as it may "push" Member States that want to avoid its effects to introduce-as was recently considered in Romania ${ }^{29}$ - a constitutional ban on same-sex marriage. However, Member States should bear in mind that such a move would not shield them from

\footnotetext{
27 United States $v$ Windsor, 570 US 744 (2013) and Obergefell $v$ Hodges, 576 US (2015).

28 Coman Judgment supra n 1, [47-50].

29 On 6 and 7 October 2018 (and less than a month since it was announced), a referendum took place in Romania asking whether the Romanian Constitution should be amended to comprehensively ban samesex marriage by changing the definition of "family" from one referring to "a union between spouses" to one making explicit reference to "a union between a man and a woman". The referendum failed to reach the required $30 \%$ turnout threshold and, thus, its result was not valid.
} 
the effects of the ruling: the EU principle of supremacy provides that EU law prevails even over constitutional provisions of a Member State, ${ }^{30}$ where there is a conflict between the two, and thus Coman requires even Member States that have a constitutional ban on same-sex marriage to recognise such a marriage in situations that fall within the scope of EU law.

The judgment has great symbolic importance, in that it demonstrates-as noted in the previous sub-section - that for the purposes of EU law, married same-sex couples are in the same position as married opposite-sex couples. Unlike in previous politically sensitive cases, ${ }^{31}$ where the ECJ refrained from conducting the balancing exercise at the justification stage itself and tossed this "hot potato" to the referring court instead, in this ruling, it did proceed to explain that obstacles to free movement which emerge from a refusal to grant family reunification rights to an LGB Union citizen married to a person of the same sex, can under no circumstances be justified. This is hugely significant, both practically and symbolically, in that the Court has demonstrated that it has zero tolerance for Member States' attempts to discriminate against LGB persons and their relationships, in situations which fall within the scope of EU law.

Moreover, although the case raised the issue of the recognition of same-sex marriages in a rather narrow context, it clearly has the potential to lead to marriage equality in a much wider range of circumstances. If we consider the Coman case itself, the ruling simply requires Romania to recognise Mr. Hamilton as the spouse of Mr. Coman and, as such, to admit him, and allow him to reside, in its territory. However, from the moment that Romania recognises Mr. Hamilton as the spouse of Mr. Coman for one purpose (i.e. his admission and residence in its territory), wouldn't it appear anomalous to refuse to treat the couple as married for other legal purposes (e.g. taxation)? Thus, even if the EU itself would be reluctant to take the additional step of requiring Member States to recognise same-sex marriages contracted in other Member States for purposes other than family reunification (if it is given the opportunity to do so), the Member States themselves might feel the need to proceed with such a step, simply because it would be impracticable not to do so. ${ }^{32}$ What is more, if Member States do take this step, this may have a domino effect in that it will make it difficult to justify treating their own nationals whose situation is not covered by EU law and who have nonetheless lawfully concluded a same-sex marriage abroad, worse than nationals of other Member States who move to their territory and worse than their own nationals who are in a Coman-like scenario.

\footnotetext{
30 Internationale Handelsgesellschaft (Case 11/70) EU:C:1970:114.

31 See, for instance, Léger v Ministre des Affaires sociales, de la Santé et des Droits des femmes and Etablissement français du sang (C-528/13), EU:C:2015:288.

32 Though, the Romanian Constitutional Court's judgment in the Coman case (after the ECJ ruled on the meaning of "spouse" and, thus, when the Romanian Court was deciding on the substance of the case) demonstrates that, at the moment, Romania will only recognise same-sex marriages in the narrow context that this is required by the ECJ Coman judgment-see E. Brodeala, "Paying lip service to the CJEU: The Unsurprising Decision of the Constitutional Court of Romania in the Coman case". Oxford Human Rights Hub. 26 July 2018 http://ohrh.law.ox.ac.uk/paying-lip-service-to-the-cjeu-the-unsurprising-decis ion-of-the-constitutional-court-of-romania-in-the-coman-case/. Last accessed on 20 August 2018.
} 


\section{Limitations of the Judgment}

Whilst the judgment in Coman should be applauded for its boldness, there are admittedly some limitations to it.

First, the Court has made repeated references in its judgment to marriages that were "concluded in a Member State in accordance with the law of that state", or made similar statements to that effect. ${ }^{33}$ Does this mean that if Mr. Hamilton and Mr. Coman happened to have married in New York instead of Brussels, the ECJ would rule that Romania was not obliged to recognise them as spouses? This is a question left unanswered by the judgment and, thus, we can only hope that the Court will be given the opportunity to clarify this in a subsequent case.

The second limitation is not one that has been specifically created for cases involving same-sex couples, given that it is a principle that was established in previous case-law involving opposite-sex couples which the Court has simply repeated in this case. This is the principle that it is only when a Union citizen has taken-up genuine residence in the territory of another Member State and during that period of genuine residence has established and strengthened family life, that (s)he can claim family reunification rights on his/her return to his/her Member State of nationality. ${ }^{34}$ In previous case-law, the Court clarified that such genuine residence can only exist when the Union citizen has settled in another Member State for at least 3 months. ${ }^{35}$ The application of this limitation in this particular context can clearly serve as a mechanism for appeasing the Member States that have not opened marriage to same-sex couples, in that it ensures that Union citizens who reside in such a Member State cannot side-step its laws, by moving with their partner to another Member State solely in order to marry and then immediately return to that State, claiming the right to be recognised as a married couple on the basis of Coman. ${ }^{36}$

Thirdly, the case is concerned only with Union citizens and their free movement rights. Hence, it does not provide an answer to the question of whether the term "spouse" includes a same-sex spouse when used in the context of the Family Reunification Rights Directive, ${ }^{37}$ which determines the conditions under which third-country nationals lawfully residing in the territory of the member States can exercise the right to family reunification (Rijpma and Koffeman 2014).

Finally, it should be highlighted that the judgment only applies in cross-border situations and thus it cannot help married same-sex couples who are in a purely

\footnotetext{
33 Coman Judgment supra n 1, [33, 35, 36, 39, 40, 42, 45, 51, 52, 56].

$34 O$ and $B$ Judgment supra n 7, [51].

35 ibid, [52-54].

36 A case involving such a scenario is currently pending before the Lithuanian Constitutional Court, to which a reference was made by the Supreme Administrative Court of Lithuania which was hearing the case: Case No. eA-4175-624/2016, 5 December 2016, http://www.lrkt.lt/ prasymai/22_2016.htm. Last accessed on 14 August 2018. For an explanation of the case see N. Bitiukova, "Gay Couple case Gives Lithuania's Highest Court a Chance to Strengthen Rights Protections". Liberties. 26 January 2017 http:// www.liberties.eu/en/news/lithuania-same-sex-couples-marriage-family-reunion/11236. Last accessed on 14 August 2018.

37 Directive 2003/86 on the right to family reunification [2003] OJ L 251/12, Art. 4.
} 
internal situation i.e. a situation which has no connection with EU law (Tryfonidou 2009). Although this, clearly, does make sense legally and, in fact, ensures that the scope of application of EU law is not extended in an unwarranted manner, one cannot help but notice that it highlights the (reverse) discrimination suffered by same-sex couples who have chosen not to-or are unable to-exercise their EU free movement rights (Kochenov 2009). For instance, if Mr. Coman had merely moved from Romania to the US, married Mr. Hamilton in the US, and returned to Romania directly from the US, the situation would be considered purely internal from the point of view of EU law (since there would be no exercise of free movement between EU Member States) and, thus, Mr. Coman would not be able to rely on EU law to require Romania to recognise Mr. Hamilton as his spouse and admit him within its territory.

\section{Conclusion}

The ruling in Coman is a very welcome first step towards marriage equality-at a cross-border level-in the EU. Same-sex couples comprised of at least one EU citizen who have married in an EU Member State, can now be certain that when they move to another Member State they will both be admitted to its territory and granted the right to reside together. Yet, the ruling does not "conclude" the matter of same-sex marriage from the point of view of EU law, but, rather, creates a number of new questions and highlights a number of gaps in the protection of same-sex couples, which persist even following the delivery of this ruling. The ruling speaks only of same-sex couples who have concluded their marriage in an EU Member State-does this mean that same-sex couples who happened to have their marriage concluded outside the EU cannot benefit from the principle established in the case? In addition, the case is concerned only with Union citizens and their free movement rights and, thus, it does not provide an answer to the question of whether the term "spouse" includes a same-sex spouse for the purpose of the grant of family reunification rights to LGB third-country nationals who are lawfully resident in the EU. Finally, the principle established by the case only applies in cross-border situations and, thus, cannot help married same-sex couples who are in a purely internal situation. Accordingly, and given that the delicate nature of the issue of the legal recognition of same-sex unions means that it is unlikely that political action will be taken to fill-in the above persisting gaps and clarify the issues that remain unresolved, it can only be hoped that the ECJ will be given the opportunity to do so in the near future.

Open Access This article is distributed under the terms of the Creative Commons Attribution 4.0 International License (http://creativecommons.org/licenses/by/4.0/), which permits unrestricted use, distribution, and reproduction in any medium, provided you give appropriate credit to the original author(s) and the source, provide a link to the Creative Commons license, and indicate if changes were made. 


\section{References}

Barnard, Catherine. 2016. The Substantive Law of the EU: The Four Freedoms. Oxford: OUP.

Bell, Mark. 2004. Holding Back the Tide? Cross-Border Recognition of Same-Sex Partnerships Within the European Union. European Review of Private Law 5: 613-632.

Bell, Chloe, and Nika Bačić Selanec. 2016. Who is a "Spouse" Under the Citizens' Rights Directive? The Prospect of Mutual Recognition of Same-Sex Marriages in the EU. European Law Review 41: 655-686.

Berneri, Chiara. 2017. Family Reunification in the EU: The Movement and Residence Rights of Third Country National Family Members of EU Citizens. Hart: Bloomsbury.

Kochenov, Dimitry. 2009. On Options of Citizens and Moral Choices of States: Gays and European Federalism. Fordham International Law Journal 33: 156-205.

Lenaerts, Koen. 2011. Federalism and the Rule of Law. Fordham International Law Journal 33: 1338-1387.

Rijpma, Jorrit, and Nelleke Koffeman. 2014. Free Movement Rights for Same-Sex Couples Under EU Law: What Role to Play for the CJEU? In Same-Sex Couples before National, Supranational and International Jurisdictions, ed. Daniele Gallo, Luca Paladini, and Pietro Pustorino, 455-491. Berlin: Springer.

Titshaw, Scott. 2016. Same-Sex Spouses Lost in Translation? How to Interpret "Spouse" in the EU Family Migration Directives. Boston University International Law Journal 34: 45-112.

Toner, Helen. 2004. Partnerships Rights, Free Movement and EU Law. Oxford: Hart.

Tryfonidou, Alina. 2009. Reverse Discrimination in EC Law. Alphen Aan den Rijn: Kluwer.

Tryfonidou, Alina. 2015. EU Free Movement Law and the Legal Recognition of Same-Sex Relationships: The Case for Mutual Recognition. Columbia Journal of European Law 21: 195-248.

Publisher's Note Springer Nature remains neutral with regard to jurisdictional claims in published maps and institutional affiliations. 